\title{
TEACHING AND LEARNING SYSTEM OF EQUATIONS IN TWO VARIABLES IN COOPERATIVE LEARNING WITH (STUDENT TEAMS ACHIEVEMENT DIVISION) STAD TYPE
}

\author{
Glory Indira Diana Purba \\ Guru Matematika SMP 2 Lubuk Pakam \\ Surel : glous_poerba@yahoo.com
}

\begin{abstract}
The purpose of this study are: describe the achievement levels of mathematical problem-solving abilities of students taught with cooperative learning strategies oriented type STAD in system of equations in two variables subject; describe the activity levels of students taught with cooperative learning STAD-oriented type of problem. This research was conducted experimental studies in State Junior High School 2 Lubuk Pakam. The selection of samples used as the experimental group and control group carried out at random (random sampling). Variables in this research is the application of cooperative learning-oriented type STAD whereas the dependent variable (dependent variable) is a mathematical problem-solving abilities of students. The data in this study were analyzed using descriptive statistical analysis and inferential analysis. Descriptive analysis intended to describe the results of students' problem-solving skills, student activities, and student response to learning.
\end{abstract}

Key words: Equation of Two Variables, Cooperative Learning

\section{PENDAHULUAN}

Dalam rangka meningkatkan prestasi belajar siswa, telah banyak upaya dilakukan untuk memperbaiki aspek-aspek yang berkaitan dengan kegiatan pembelajaran. Tercakup dalam perbaikan itu adalah perbaikan terhadap tujuan, kurikulum, pelaksanaan pembelajaran, evaluasi, juga terhadap kualifikasi guru. Upaya yang berkaitan dengan perbaikan tujuan dan kurikulum dilakukan setiap ada pemberlakuan perangkat kurikulum baru atau penyempurnaan terhadap kurikulum yang sedang diterapkan, seperti Kurikulum Berbasis Kompetensi (KBK) lalu dilakukan terhadap Kurikulum Tingkat Satuan Pendidikan (KTSP).
Berdasarkan fakta di lapangan perolehan hasil belajar matematika siswa di kedua sekolah masih rendah. Salah satu kegiatan dalam matematika yang dianggap cukup penting baik oleh guru maupun siswa di semua tingkatan mulai dari SD sampai SMA adalah kemampuan pemecahan masalah. Akan tetapi hal tersebut masih dianggap sebagai bagian yang paling sulit dalam matematika, baik bagi siswa dalam mempelajarinya maupun bagi guru dalam mengajarkannya. Fakta di lapangan menunjukkan bahwa secara umum kemampuan pemecahan masalah matematika siswa masih rendah, sebagai contoh sebagaimana yang dikemukakan oleh Saragih (2007: 12) bahwa banyak siswa kelas 
II SMP yang mengalami kesulitan untuk menyelesaikan soal cerita yang berkaitan dengan Sistem Persamaan Linier Dua Variabel, misalnya Budi memerlukan tambahan untuk membuat teras dengan membeli 3 kotak keramik A dan 2 kotak keramik $\mathrm{B}$ dengan harga Rp. 13.000,-. Sedangkan tetangga Budi membeli 2 kotak keramik A dan 4 kotak keramik B di tempat yang sama dengan harga Rp. 14.000,-Berapa harga 1 kotak keramik A dan berapa harga 1 kotak keramik B? Hasil penelitian Suryadi (Saragih, 2007: 192) menemukan bahwa siswa kelas dua SMP di kota dan Kabupaten Bandung mengalami kesulitan dalam kemampuan mengajukan argumentasi serta menemukan pola dan pengajuan bentuk umumnya.

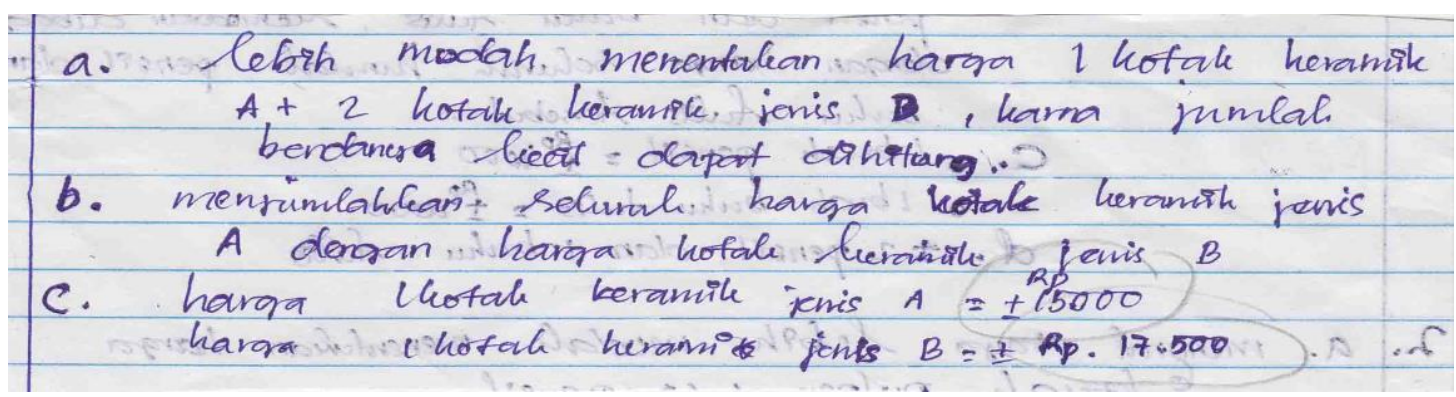

Gambar 1. Pola jawaban siswa untuk soal Sistem Persamaan

\section{Linier Dua Variabel}

Pembelajaran matematika beserta sistem evaluasi selama ini kurang memberikan kesempatan bagi siswa untuk memunculkan gagasangagasan / ide - ide selama siswa belajar matematika (Hasanah, 2004: 21). Hal ini disebabkan karena pembelajaran lebih terpusat kepada guru (teacher-centered) yang umumnya telah siap mentransferkan ilmunya langsung kepada siswa, dengan kata lain guru yang aktif sedangkan siswa pasif selama belajar. Pembelajaran tersebut lebih menekankan pada hasil (product) dimana siswa tinggal menerapkan atau menggunakan rumus algoritma daripada menekankan pada proses.
Dengan demikian sebagian besar aktifitas belajar matematika adalah bersifat berlatih menyelesaikan soalsoal (drill) atau soal-soal rutin.

Untuk

memperoleh

kemampuan dalam pemecahan masalah seseorang harus memiliki banyak pengalaman dalam memecahkan berbagai masalah. Anak yang diberi banyak latihan pemecahan masalah dengan tujuan agar memiliki nilai lebih tinggi dalam pemecahan masalah dibandingkan dengan anak yang latihannya lebih sedikit. Dari beberapa pandangan tentang pemecahan masalah dapat ditarik suatu kesimpulan bahwa pemecahan 
masalah sebagai tujuan inti dan utama dalam kurikulum matematika berarti dalam pembelajaran matematika lebih mengutamakan proses siswa menyelesaikan masalah daripada sekedar hasil, sehingga kemampuan pemecahan masalah dijadikan sebagai kemampuan dasar yang harus dimiliki siswa dalam belajar matematika.

Menurut Johnson dan Johnson (Polya, 2001: 3), pembelajaran kooperatif berpotensi membantu para siswa untuk mengembangkan: permasalahan matematika, pemecahan masalah dan pengertian yang mendalam, keyakinan diri. Sehingga untuk tujuan ini, dapat dilakukan pembelajaran dengan menggunakan strategi pembelajaran secara kooperatif. Menurut Karli dan Yuliariati Ningsih (2000: 70).

Menurut Ibrahim, dkk (2000:3), pembelajaran kooperatif menuntut kerjasama siswa dan saling ketergantungan dalam struktur tugas, tujuan, dan hadiah/penghargaan. Struktur tugas mengacu kepada 2 hal, yaitu pada cara pembelajaran itu diorganisasikan dan jenis kegiatan yang dilakukan oleh siswa di dalam kelas. Struktur tujuan suatu pembelajaran adalah jumlah saling ketergantungan yang dibutuhkan siswa pada saat mereka mengerjakan tugas. Struktur tujuan kooperatif terjadi jika siswa dapat mencapai tujuan mereka hanya jika siswa lain dengan siapa mereka bekerja sama mencapai tujuan tersebut. Tujuan kelompok akan tercapai apabila semua anggota kelompok mencapai tujuannya secara bersama-sama. Sementara struktur penghargaan dalam pembelajaran kooperatif ialah ibarat pemenang suatu pertandingan olah raga beregu seperti sepak bola. Meskipun regu tersebut harus bersaing dengan regu lain, namun keberhasilan regu tidaklah akibat keberhasilan 1 atau 2 orang saja melainkan karena keberhasilan bersama anggota regu tersebut.

Pembelajaran kooperatif dapat membantu para siswa meningkatkan sikap posistif dalam matematika. Para siswa secara individu membangun kepercayaan diri terhadap kemampuannya untuk menyelesaikan masalah-masalah matematika. Hal ini akan dapat mengurangi bahkan menghilangkan rasa cemas terhadap matematika (mathematics anxiety) yang banyak dialami para siswa. Pentingnya hubungan antar teman sebaya di dalam ruang kelas tidaklah dapat dipandang remeh. Pengaruh teman sebaya pada pembelajaran kooperatif yang ada di dalam kelas dapat digunakan untuk tujuan-tujuan positif dalam pembelajaran matematika. Para siswa menginginkan teman-teman dalam kelompoknya siap dan produktif di dalam kelas. Dorongan teman untuk mencapai prestasi akademik yang baik adalah salah satu faktor penting dari pembelajaran tersebut. Cara ini telah terbukti dapat meningkatkan berfikir kritis serta meningkatkan kemampuan siswa dalam pemecahan masalah (Suherman, dkk, 2003: 159). 
Salah satu tipe dalam pembelajaran kooperatif adalah Student Teams Achievement Divisions (STAD), yaitu suatu pembelajaran secara berkelompok yang beranggotakan $4-6$ orang, merupakan campuran laki-laki dan perempuan dengan tingkat kemampuan beragam. Pada pembelajaran kooperatif tipe STAD siswa selalu diberi motivasi untuk saling membantu dan saling membelajarkan teman sekelompoknya dalam memahami materi pelajaran serta untuk menyelesaikan tugas akademik dalam rangka mencapai ketuntasan belajar yang maksimal.

Pembelajaran yang didapat oleh siswa selama di bangku sekolah seharusnya berupa pengalaman yang dapat digunakan untuk bekal hidup dan untuk bertahan hidup. Tugas seorang guru di sini bukan hanya sekedar mengajar (teaching) tetapi lebih ditekankan pada pembelajaran (learning) dan mendidik. Pembelajaran tidak hanya ditekankan pada keilmuannya semata. Arah pembelajaran seharusnya berfokus pada belajar, seperti: learning how to know, learning how to do, learning how to be, dan learning how to live together (Utari-Sumarmo, 2005: 5).

Hudojo (1998: 3) mengemukakan bahwa matematika berkenaan dengan ide-ide (gagasan-gagasan), strukturstruktur, dan hubungan-hubungannya yang diatur secara logik sehingga matematika berkenaan dengan konsep-konsep yang abstrak. Selanjutnya Soedjadi (1995:5) mengemukakan bahwa matematika sebagai ilmu dalam batas tertentu disusun secara deduktif aksiomatik yang diawali dengan pernyataan pangkal dan selanjutnya diturunkan sebagai teorema tertentu atau dilengkapi dengan berbagai definisi. Matematika sebagai bahan pelajaran yang objek kajiannya berupa fakta, konsep, operasi, dan prinsip yang abstrak, dalam mempelajarinya diperlukan kegiatan psikologis seperti mengabstraksi dan mengklasifikasi. Mengabstraksi merupakan kegiatan memahami kesamaan sejumlah objek atau situasi yang berbeda. Sedangkan mengklarifikasi merupakan kegiatan memahami cara mengelompokkan objek atau situasi berdasarkan kesamaannya

Oleh karena itu Freudenthal (1993: 72) menyatakan bahwa konsep matematika tidak boleh diberikan dalam bentuk jadi ( r ready made product). Dari kutipan ini dapat dimaknai bahwa konsepkonsep yang ada dalam matematika tidak boleh dipindahkan langsung dari guru ke siswa sebab di dalamnya mengandung proses abstraksi, dimana siswa harus dilibatkan dalam proses penemuan konsep. Siswa dituntut menciptakan ide-ide, mencari hubungan-hubungan membentuk konsep. Tentu dalam hal ini, setiap siswa mempunyai persepsi, ide-ide yang berbeda dalam memandang objek yang diabstraksikan, tergantung pada konsep atau pengalaman belajar yang dimiliki sebelumnya. 
Belajar matematika adalah suatu proses psikologis berupa kegiatan aktif dalam upaya seseorang untuk rekonstruksi, memahami atau menguasai materi matematika agar tercapai tujuan belajar. Tujuan belajar matematika ditinjau dari segi kognitif adalah terjadinya transfer belajar. Hudojo (1998: 102) menyatakan transfer belajar berkenan dengan adanya konsep dan terutama matematika yang telah terorganisasi di dalam pikiran sehingga dengan adanya konsep dan teorema dapat digunakan untuk menyelesaikan masalah yang dihadapi. Transfer belajar matematika dapat dilihat dari kemampuan seseorang memfungsionalkan materi matematika yang telah dipelajari, baik secara konseptual maupun secara praktis. Secara konseptual dimaksudkan dapat mempelajari matematika lebih lanjut. Sedangkan secara praktis dimaksudkan menerapkan konsep-konsep dan prinsip matematika pada bidang lain dan memecahkan masalah dalam kehidupan nyata.

Secara umum pemecahan masalah (problem solving) adalah belajar memecahkan masalah. Pada tingkat ini para peserta didik belajar merumuskan memecahkan masalah, memberikan respons terhadap rangsangan yang menggambarkan atau membangkitkan situasi problematik yang mempergunakan berbagai kaidah yang dikuasainya. Menurut John Dewey (dalam Djamarah,1994: 18) belajar memecahkan masalah itu berlangsung sebagai berikut: individu menyadari masalah bila ia dihadapkan kepada situasi keraguan dan kekaburan sehingga merasakan adanya semacam kesulitan.

Dalam belajar matematika, pemecahan masalah merupakan salah satu hasil belajar yang ingin dicapai, dan merupakan suatu hal yang sangat penting. Bahkan sering dikatakan bahwa pemecahan masalah adalah jantungnya matematika. Dalam matematika pemecahan masalah dapat dipandang sebagai kemampuan dasar, sebagai proses dan tujuan (Utari, 1993:7). Lebih lanjut Utari (1993: 8), mengemukakan bahwa pemecahan masalah sebagai kemampuan dasar merupakan jawaban pertanyaan yang kompleks, bahkan lebih kompleks dari pengertian pemecahan masalah itu sendiri. Namun ada dua pengertian pemecahan masalah sebagai kemampuan dasar yang banyak digunakan adalah: (1) kemampuan minimum yang harus dimiliki siswa dan dievaluasi di tingkat lokal dan nasional, dan (2) kemampuan minimum yang diperlukan siswa agar dapat berfungsi dalam masyarakat. Sedangkan pandangan bahwa pemecahan masalah sebagai proses, merupakan suatu kegiatan yang lebih mengutamakan pentingnya prosedur, langkahlangkah, strategi dan heuristik yang ditempuh siswa dalam menyelesaikan masalah, sehingga dapat menemukan jawaban soal dan bukan hanya pada jawaban itu sendiri. Adapun pandangan bahwa 
pemecahan masalah sebagai tujuan berkaitan dengan pertanyaan, Mengapa matematika diajarkan? dan Apa tujuan pengajaran matematika itu? Jawaban dari kedua pertanyaan tadi, dikemukakan oleh Utari, adalah karena matematika merupakan bidang studi yang berguna dan membantu dalam menyelesaikan berbagai masalah. Matematika sebagai alat untuk membangkitkan serta melatih kemampuan pemecahan masalah.

Pada mata pelajaran matematika, pemecahan masalah dapat berupa soal cerita atau soal yang tidak rutin, yaitu soal yang untuk sampai pada prosedur yang benar diperlukan pemikiran yang mendalam. Namun permasalahan yang muncul adalah seringkali siswa tidak memiliki cukup pengetahuan untuk memilih strategi yang tepat untuk digunakan dalam menyelesaikan soal-soal tersebut, yang mungkin dapat diterapkan untuk memecahkan masalah yang dihadapainya. Pemecahan masalah dapat meningkatkan kemampuan berfikir kritis, logis, kreatif, dan sistematis. Polya (Sumarmo,1994: 2) memberikan alternatif dalam pemecahan masalah dapat ditempuh melalui empat tahapan yaitu (1) memahami masalah; (2) membuat rencana pemecahan; (3) melakukan penghitungan; (4) memeriksa kembali hasil yang diperoleh. Sementara dalam upaya pemecahan masalah, Sumarmo (1991: 23) mengemukakan bahwa langkahlangkah yang perlu dikembangkan dalam proses pemecahan masalah adalah sebagai berikut :

a. Siswa memahami masalahnya. Pemahaman siswa tentang masalah yang dihadapi dapat diketahui dari kemampuan siswa mengidentifikasi fakta dan kondisi, menyebutkan tujuan yang ingin dicapai, serta mentransfer situasi masalah menjadi situasi matematis.

b. Siswa menyusun strategi penyelesaian, beberapa petunjuk yang dapat digunakan untuk mengetahui kemampuan siswa untuk menyusun strategi adalah beberapa pilihan (alternatif) strategi yang dihasilkan siswa, adanya usaha siswa menggunakan fakta dan kondisi yang tersedia serta adanya estimasi jawaban atau penyelesaian.

c. Siswa melaksanakan strategi. Kemampuan melaksanakan strategi dapat ditunjukkan dengan pembuatan tabel, sampai diperoleh jawaban atau penyelesaian.

d. Siswa melaksanakan pengujian jawaban. Kemampuan melaksanakan pengujian dapat ditunjukkan dari proses interpretasi dan evaluasi jawaban yang diperoleh".

Untuk mengukur kemampuan pemecahan masalah, tentunya diperlukan alat ukur yang berbeda dengan alat ukur yang digunakan untuk mengukur kemampuan kognitif tingkat rendah. Untuk itu 
pemberian skor tes kemampuan pemecahan masalah tentu berbeda dengan pemberian skor obyektif. Dalam tes obyektif pemberian skornya terfokus pada hasil, sedangkan pada pemecahan masalah tidak saja mengukur hasil, tetapi juga memperhatikan proses bagaimana cara untuk dapat menyelesaikan suatu permasalahan (soal).

Inti dari STAD adalah guru menyampaikan suatu materi, sementara para siswa tergabung dalam kelompoknya yang terdiri atas 4 sampai 6 orang dan setiap kelompok heterogen, terdiri dari lakilaki dan perempuan, memiliki kemampuan tinggi, sedang, dan rendah untuk menyelesaikan soalsoal yang diberikan oleh guru. Selanjutnya, siswa diberi kuis/tes secara individual. Skor hasil kuis/tes tersebut disamping untuk menentukan skor individu juga digunakan untuk menentukan skor kelompoknya. Anggota tim menggunakan lembar kegiatan atau perangkat pembelajaran yang lain untuk menuntaskan pelajarannya dan kemudian saling membantu satu sama lain untuk memahami bahan pelajaran melalui tutorial, kuis, satu sama lain dan atau melakukan diskusi. Secara individual diberikan kuis pada masing-masing siswa. Kuis itu diskor, dan tiap individu diberi skor perkembangan. Dari uraian di atas, maka dapat diringkas bahwa prosedur atau langkah-langkah dalam pembelajaran kooperatif ada 6 fase, yaitu: (1) Menyampaikan tujuan pembelajaran dan membangkitkan motivasi; (2) Menyajikan informasi kepada siswa dengan demonstrasi disertai penjelasan verbal, buku teks, atau bentuk-bentuk lain; Mengorganisasikan dan membantu kelompok belajar; (4) Mengelola dan membantu kerja kelompok; Menguji penguasaan kelompok atas bahan ajar; (6) Memberi penghargaan atau pengakuan terhadap hasil belajar siswa (Ibrahim, dkk, 2000; 88). Berikut akan dijelaskan secara lebih rinci.

Beberapa aspek dari penyampaian tujuan dan memotivasi siswa tidak berbeda untuk pembelajaran kooperatif dibandingkan dengan model-model lainnya. Guru yang berhasil, memulai pelajaran dengan menelaah ulang, menjelaskan tujuan mereka dengan bahasa yang mudah dipahami, dengan menunjukkan bagaimana pelajaran itu terkait dengan pembelajaran sebelumnya. Guru pembelajaran kooperatif seharusnya memberikan perhatian khusus untuk menjelaskan tujuan pembelajaran dan motivasi siswa, mengingat pelajaran itu sering berlanjut sampai beberapa hari. Mungkin juga perlu waktu untuk mendiskusikan bagaimana pengetahuan datang dari sumber, seperti buku dan interaksi diri sendiri dengan orang lain.

Poin penting dalam hal ini adalah agar siswa berkemungkinan untuk bekerja ke arah tujuan-tujuan penting dari pelajaran yang telah didiskusikan secara khusus. Sulit bagi siswa untuk melaksanakan suatu 
tugas dengan baik apabila mereka belum jelas tentang mengapa mereka melakukan kegiatan itu atau apabila kriteria keberhasilan tidak diberitahukan secara terbuka.

$$
\text { Apabila pembelajaran }
$$

kooperatif menghendaki siswa untuk membaca suatu teks, maka guru yang berhasil tidak saja memandang tingkat usia siswa-siswa mereka atau mata pelajaran yang diajarkan, tetapi juga seharusnya mengasumsikan tanggung jawab untuk membantu siswa menjadi pembaca yang lebih baik. Pada tahap ini guru memulai dengan menyampaikan tujuan pembelajaran khusus dan memotivasi rasa ingin tahu siswa tentang materi yang akan dipelajari. Dilanjutkan dengan memberikan apersepsi dengan tujuan mengingatkan siswa terhadap materi prasyarat yang telah dipelajari, agar siswa dapat menghubungkan materi yang akan disajikan dengan pengetahuan yang telah dimiliki. Mengenai teknik penyajian materi pelajaran dapat dilakukan secara klasikal ataupun melalui diskusi.

Mengorganisasikan siswa ke dalam kelompok-kelompok belajar dan meminta mereka mulai menangani tugas mereka merupakan satu langkah paling sulit bagi guru dalam menggunakan pembelajaran kooperatif saat mana dapat terjadi kegaduhan kecuali peralihan direncanakan dan dikelola secara seksama.

Ada suatu aturan untuk diikuti guru selama fase ini dalam suatu pelajaran pembelajaran kooperatif. Ikut campur yang terlampau banyak atau bantuan yang tidak diinginkan dapat mengganggu siswa. Hal ini juga dapat meniadakan kesempatan siswa untuk berinisiatif dan bekerja dengan arahan diri sendiri. Pada saat yang sama, apabila guru menemukan bahwa siswa tidak jelas tentang petunjuk atau mereka tidak dapat menyelesaikan tugastugas kelompok yang diberikan, maka guru harus melakukan intervensi dan menawarkan bantuan. Singkatnya, guru perlu memberi siswa bantuan pada saat mereka memerlukannya, namun harus mengenali seberapa penting bantuan itu bagi siswa agar mereka lebih saling bergantung satu sama lain, daripada bergantung pada guru.

Pada tahap ini setiap kelompok diberi lembar tugas sebagai bahan yang akan dipelajari. Dalam kerja kelompok ini siswa saling berbagi tugas, saling membantu memberikan penyelesaian agar semua anggota kelompok dapat memahami materi yang dibahas, dan satu lembar dikumpulkan sebagai hasil kerja kelompok. Pada tahap ini guru berperan sebagai fasilitator dan memotivator kegiatan tiap kelompok.

Guru memberikan kuis kepada siswa tentang materi pembelajaran. Butir -butir soal yang diberikan itu dapat diskor di kelas atau segera setelah tes itu diberikan. Butir-butir tes tersebut berupa soalsoal, berkaitan dengan materi yang baru saja disajikan. Pada penelitian ini diadakan tes secara individual, mengenai materi yang telah dibahas. 
Tes diadakan setiap selesai pembelajaran setiap kali pertemuan, selama 10-15 menit, agar siswa dapat menunjukkan apa yang telah dipelajari secara individu selama bekerja dalam kelompok. Skor perolehan individu ini didata dan diarsipkan, yang akan digunakan pada perhitungan perolehan skor kelompok.

\section{METODOLOGI PENELITIAN}

Penelitian ini menggunakan metode quasi eksperimen yang membandingkan dua strategi pembelajaran yaitu strategi pembelajaran kooperatif tipe STAD yang berorientasikan masalah dan strategi pembelajaran ekspositori. Penelitian dilakukan di kelas VIII SMP Negeri 2 Lubuk Pakam.

Adapun teknik pemilihan tempat penelitian ditentukan menggunakan cara purposif. Alasan / pertimbangan dipilihnya kelas VIII SMP adalah: (1) Siswa kelas VIII merupakan siswa menengah pada jenjangnya yang sudah dapat menyesuaikan diri dengan lingkungan sekolahnya ; (2) Menurut penelitian mengenai perkembangan mental anak-anak Indonesia yang dilakukan oleh Ruseffendi, tahap perkembangan mental siswa berada pada tahap operasi konkrit ; (3) Pada kelas VIII, terdapat materi yang dianggap tepat disampaikan dengan pembelajaran kooperatif tipe STAD yaitu Sistem Persamaan Linier Dua Variabel ; (4) Siswa telah menerima cukup banyak materi prasyarat untuk menunjang materi yang dipilih sebagai bahan ajar penelitian. Sedangkan alasan tidak dipilihnya kelas VII dan kelas IX sebagai objek populasi yaitu pada siswa kelas VII merupakan siswa baru, mereka masih dalam tahap transisi dan penyesuaian. Sedangkan siswa kelas IX merupakan kelas yang sedang secara khusus dipersiapkan untuk menghadapi Ujian Nasional (UN) / ujian akhir sehingga apabila digunakan sebagai objek penelitian ini akan mengganggu kegiatan yang sudah dijadwalkan.

Sesuai dengan tujuan penelitian yakni untuk mengungkap ada tidaknya perbedaan kemampuan pemecahan masalah antara siswa yang mengikuti pembelajaran matematika dengan strategi pembelajaran kooperatif tipe STAD yang berorientasikan masalah dengan siswa yang mengikuti pembelajaran matematika dengan strategi ekspositori. Uji coba pengembangan perangkat dan instrumen menggunakan uji awal dan uji akhir (pretest - postest control group design) yang dilakukan di SMP Negeri 2 Lubuk Pakam. Untuk lebih jelasnya metode desain penelitian ini digambarkan sebagai berikut:

$$
\begin{array}{llll}
\mathrm{R} & \mathrm{O} & \mathrm{X} & \mathrm{O} \\
\mathrm{R} & \mathrm{O} & - & \mathrm{O}
\end{array}
$$

Keterangan :

$\mathrm{R}$ : Pengelompokan secara random

O : Pretes/Postes, dan

$X$ : Strategi pembelajaran kooperatif tipe STAD 
Usaha untuk mengetahui sejauh mana perbedaan antara variabel-variabel yang dapat dikatakan sebagai tujuan dari penelitian. Pada penelitian ini baik pembelajaran kooperatif tipe STAD yang berorientasikan masalah maupun pembelajaran dengan strategi ekspositori merupakan variabel bebas yang mempengaruhi. Sementara kemampuan pemecahan masalah siswa, yang ditinjau dari memahami masalah, membuat rencana pemecahan masalah, melakukan penghitungan, dan memeriksa kembali hasil yang diperoleh dalam menyelesaikan soal SPLDV merupakan variabel terikat atau variabel yang dipengaruhi.

\section{Rancangan Penelitian}

Penelitian ini dirancang untuk mengetahui bahwa penerapan pembelajaran kooperatif tipe STAD dapat lebih meningkatkan kemampuan pemecahan masalah matematika siswa jika dibandingkan dengan penerapan pembelajaran ekspositori. Adapun rancangan yang telah dilaksanakan dalam penelitian ini adalah sebagai berikut.

a. Sampel penelitian ditentukan dengan menggunakan teknik cluster random sampling, dengan pertimbangan siswa mendapat materi berdasarkan kurikulum yang sama, siswa diajar oleh guru yang sama, siswa yang menjadi objek penelitian duduk pada kelas yang sama, dan pembagian kelas tidak ada kelas unggulan.
Dipilih dua kelas sebagai kelas eksperimen dan kelas kontrol. Kemudian menentukan kelas uji coba di luar sampel penelitian.

b. Setelah ditentukan sampel penelitian, kemudian untuk mengetahui apakah sampel penelitian berangkat dari titik tolak yang sama maka perlu diadakan uji normalitas data awal dan uji homogenitas data awal. Ujicoba ini dilaksanakan di salah satu kelas VIII di SMP Negeri 2 Lubuk Pakam.

c. Kemudian menyusun kisi-kisi tes dan menyusun instrumen uji coba berdasarkan kisi-kisi yang ada.

d. Instrumen uji coba diujikan pada kelas uji coba yang sebelumnya telah diajarkan materi pokok SPLDV, di mana instrumen tersebut akan diujikan sebagai tes kemampuan pemecahan masalah pada kelas yang dikenai pembelajaran kooperatif tipe STAD dan pembelajaran ekspositori.

e. Data hasil uji coba instrumen pada kelas uji coba dianalisis untuk mengetahui validitas, reliabilitas, tingkat kesukaran, dan daya pembeda.

f. Soal-soal yang memenuhi syarat, kemudian akan dijadikan soal tes kemampuan pemecahan masalah pada kelas yang dikenai pembelajaran kooperatif tipe STAD dan kelas yang dikenai pembelajaran ekspositori. 
g. Menentukan langkah-langkah dan prosedur pembelajaran kooperatif tipe STAD yang berorientasikan masalah dan pembelajaran ekspositori yang dituangkan dalam Rencana Pembelajaran (RP).

h. Melaksanakan pembelajaran kooperatif tipe STAD dan pembelajaran ekspositori pada kelas yang menjadi sampel penelitian.

i. Pembagian kelompok ditentukan sebelum pelaksanaan kegiatan pembelajaran kooperatif tipe STAD dan pembelajaran ekspositori. Hal ini dilakuakan untuk menghindari kekurangan waktu saat pembelajaran berlangsung.

j. Sebelum diadakan pembelajaran, terlebih dahulu diadakan pretes pada kelas yang dikenai pembelajaran kooperatif tipe STAD dan kelas yang dikenai pembelajaran ekspositori.

k. Melaksanakan / menerapkan pembelajaran kooperatif tipe STAD di kelas eksperimen dan pembelajaran ekspositori di kelas kontrol.

1. Menganalisis data tes kemampuan pemecahan masalah dan aktifitas siswa yang diambil pada kelas yang dikenai pembelajaran kooperatif tipe STAD dan kelas yang dikenai pembelajaran ekspositori.

m. Menyusun hasil penelitian. n. Mendeskripsikan hasil penelitian dan membuat kesimpulan.

\section{Instrumen Penelitian}

Instrumen yang digunakan dalam mengumpulkan data pada penelitian ini adalah bentuk tes dan non tes. Bentuk tes yang digunakan adalah tes kemampuan pemecahan masalah. Tes digunakan untuk mengukur peguasaan dan kemampuan yang dicapai seseorang dalam berbagai bidang pengetahuan). Agar tes memenuhi validitas isi, bisa dilakukan dengan cara menyusun tes yang bersumber daru kurikulum bidang studi yang hendak diukur (Arikunto, 2001: 67). Tes yang digunakan disesuaikan dengan kurikulum tujuan yang ingin dicapai yang diambil dari buku pelajaran matematika kelas VIII. Di sekolah sebagai tempat penelitian, tes dilakukan sebelum dan sesudah pelaksanaan pembelajaran (pretes dan postes), baik pada kelas eksperimen maupun pada kelas kontrol. Fokus penelitian ini adalah untuk menilai : (1) aspek pemecahan masalah, dengan indikasi siswa mampu menuliskan data apa yang diketahui dan apa yang ditanyakan dari soal dalam bentuk dua variabel, (2) aspek membuat rencana pemecahan, dengan indikasi siswa mampu menentukan suatu sistem persamaan linier dua variabel dari data yang diketahui dan yang ditanyakan (3) aspek melakukan penghitungan, dengan indikasi siswa mampu menyelesaikan perhitungan 
dari sistem persamaan linier dua variabel sebagai jawaban yang diinginkan (4) aspek memeriksa kembali hasil yang diperoleh, dengan indikasi siswa menguji kebenaran/keabsahan jawaban apakah sesuai dengan batasanbatasan yang ada dalam soal.

\section{Analisis Data}

Data yang diperoleh dari skor tes hasil kemampuan pemecahan masalah matematika dikelompokkan menurut kelompok pendekatan pembelajaran (kooperatif tipe STAD dan ekspositori). Pengolahan data diawali dengan menguji persyratan statistic yang diperlakukan sebagai dasar dalam pengujian hipotesis antara lain uji normalitas dengan uji Liliefors dan homogenitas dengan Uji Barlett. Hasil perhitungan menunjukkan uji persyaratan analisis dipenuhi. Selanjunya dilakukan uji t yang disesuaikan dengan permasalahannya. Seluruh perhitungan statistic menggunakan program SPSS.

\section{HASIL PENELITIAN DAN PEMBAHASAN}

Berdasarkan hasil pengujian hipotesis diperoleh $\mathrm{Fc}$ sebesar 15,858 , sementara nilai kritis $F_{\text {tabel }}$ dengan $\mathrm{dk}=(1,55)$ dan $\alpha=5 \%$ adalah sebesar 1,44. Hasil ini menunjukkan bahwa $F_{\text {hitung }}=6,152>$ $\mathrm{F}_{\text {tabel }}=1,44$ sehingga hipotesis nol $\left(\mathrm{H}_{\mathrm{o}}\right)$ ditolak, dengan demikian hipotesis penelitian yang menyatakan bahwa terdapat perbedaan kemampuan pemecahan masalah anatar siswa yang diajarkan dengan kooperatif tipe STAD dan siswa yang diajarakan dengan ekspositori teruji kebenarannya dengan topic pembelajaran SPLDV.

Berdasarkan hasil penelitian dari analisis yang dilakukan di atas, menunjukkan bahwa pembelajaran dengan strategi kooperatif tipe STAD yang berorientasikan masalah lebih baik dalam meningkatkan kemampuan pemecahan masalah matematika siswa dibandingkan dengan strategi pembelajaran ekspositori, demikian juga halnya aktifitas siswa lebih kreatif. Dari hasil pengamatan terjadinya perbedaan dari kedua strategi pembelajaran tersebut adalah wajar. Secara teoritis pembelajaran kooperatif tipe STAD yang berorientasikan masalah memiliki beberapa keunggulan bila dibandingkan dengan pembelajaran ekspositori. Keunggulan tersebut menyangkut karakteristik dari pembelajaran dengan kooperatif tipe STAD yaitu : menggunakan model, menggunakan kontribusi dan produksi siswa, interaktif, dan keterkaitan.

Teknik pembelajaran kooperatif lebih unggul dalam meningkatkan hasil belajar dibandingkan dengan pengalamanpengalaman belajar individual (secara klasikal). Tugas-tugas yang kompleks seperti pemecahan masalah, berpikir kritis, dan pembelajaran konseptual meningkat secara nyata pada saat digunakan 
strategi-strategi kooperatif. Siswa lebih memiliki kemungkinan menggunakan tingkat berpikir yang lebih tinggi selama dan setelah diskusi dalam kelompok kooperatif daripada mereka bekerja secara individual. Sehingga siswa secara formal, materi yang dipelajari siswa akan melekat untuk periode waktu yang lebih lama.

Pembelajaran kooperatif dapat memberikan keuntungan, baik bagi siswa kelompok bawah maupun kelompok atas yang bekerja sama menyelesaikan tugas akademik. Siswa kelompok atas akan meningkat kemampuan akademiknya karena memberi pelayanan. Sebagai tutor membutuhkan pemikiran lebih mendalam tentang hubungan ide-ide yang terdapat di dalam materi tertentu. Sedangkan bagi siswa kelompok bawah, mereka dapat belajar bersama-sama dengan temanteman dalam kelompoknya sehingga mereka dapat saling berbagi pengetahuan.

Lembar Aktifitas Siswa (LAS) juga dirancang sesuai dengan konsep dasar untuk meningkatkan kemampuan pemecahan masalah matematika siswa untuk materi SPLDV. LAS dikerjakan secara kooperatif (diskusi kelompok). Dalam kerja kelompok ini siswa saling berbagi tugas, saling membantu memberikan penyelesaian agar semua anggota kelompok dapat memahami materi yang dibahas, dan satu lembar dikumpulkan sebagai hasil kerja kelompok. Selanjutnya hasil kerja kelompok tersebut dipresentasikan oleh beberapa kelompok. Untuk itu, siswa dituntut aktif dalam menyajikan hasil maupun bertanya. Sedangkan dalam pembelajaran ekspositori, siswa cenderung pasif karena cenderung hanya mendengarkan penjelasan guru, dan mengerjakan soal semata.

Dalam pembelajaran kooperatif tipe STAD, guru memberikan kuis individual sebagai umpan balik untuk menguji kemampuan siswa terhadap materi yang baru saja dipelajari dan disajikan. Hal ini juga dapat mendorong siswa untuk lebih serius saat berdiskusi dengan teman sekelompoknya. Karena skor dari kuis individual ini nantinya akan digabung dengan skor dari siswa yang berada dalam satu kelompok, dan itulah yang akan menjadi skor kelompok mereka. Keseriusan dalam belajar kelompok dapat membantu siswa untuk memecahkan masalah lebih cepat jika dibandingkan dengan belajar secara individual.

Pembelajaran kooperatif tipe STAD yang berorientasikan masalah menimbulkan interaksi antara siswa dengan siswa maupun guru dengan siswa yang merupakan hal terpenting dalam pengukuran aktifitas siswa. Siswa berperan aktif dalam proses pembelajaran kooperatif tipe STAD dibandingkan dengan pembelajaran ekspositori. Kontribusi antar siswa dalam pembelajaran terlihat saat berdiskusi dengan teman sekelompoknya untuk memecahkan masalah yang tertuang dalam LAS, dan saat presentasi (penyajian hasil). 
Demikian juga interaksi siswa terhadap guru terjadi saat diskusi dimana guru harus mampu melakukan intervensi apabila menemukan bahwa siswa tidak jelas tentang petunjuk atau mereka tidak dapat menyelesaikan tugas-tugas kelompok yang diberikan, namun harus mengenali seberapa penting bantuan itu bagi siswa agar mereka lebih saling bergantung satu sama lain, daripada bergantung pada guru. Sealain itu, guru dan siswa dalam pembelajaran kooperatif tipe STAD bersama-sama membuat kesimpulan dari hasil presentasi yang telah disajikan. Oleh sebab itu, interaksi yang terjadi bersifat multi arah, berbeda dengan pembelajaran ekspositori dimana guru hanya sebagai sumber informasi dan pengetahuan bagi siswa.

Dari 7 butir tes kemampuan pemecahan masalah yang digunakan oleh siswa, terdapat variasi dan keragaman sesuai dengan daya nalar masing-masing siswa. Pola jawaban siswa yang memperoleh pembelajaran kooperatif tipe STAD lebih sitematis dibandingkan dengan hasil pola jawaban siswa yang memperoleh pembelajaran dengan ekspositori. Demikian juga keragaman jawaban siswa lebih bervariasi pada kelompok yang mendapat pembelajaran ekspositori. Pemecahan masalah memuat 4 aspek yaitu: memahami masalah, membuat rencana pemecahan masalah, melakukan penghitungan, dan memerikasa hasil kembali. Dengan melihat keempat aspek tersebut, terdapat perbedaan kemampuan pemecahan masalah yang lebih baik pada kelompok yang mengalami pembelajaran kooperatif tipe STAD dibandingkan dengan dengan ekspositori. Untuk aspek memahami masalah, terlihat pada kedua kelompok sudah dapat memahami masalah dengan baik tetapi siswa di kelas kontrol kurang dapat menuliskan alasan-alasan logis untuk soal-soal yang meminta pendapat.

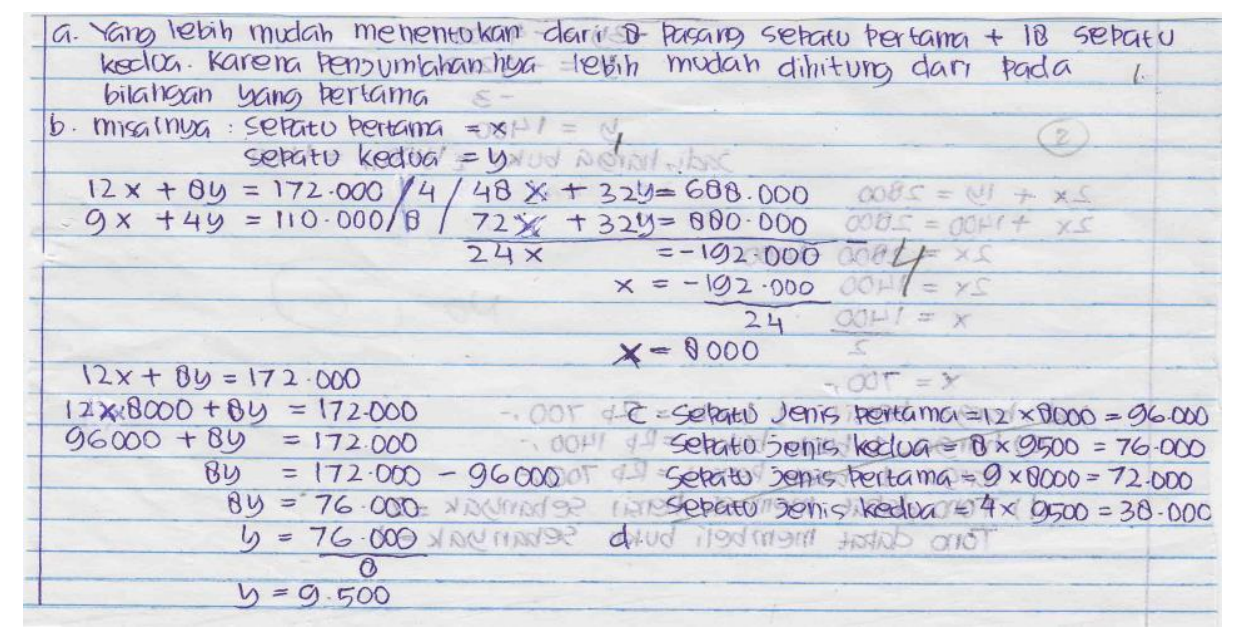

Gambar 2. Pola jawaban siswa di kelas eksperimen untuk soal SPLDV (dinilai oleh penulis) 


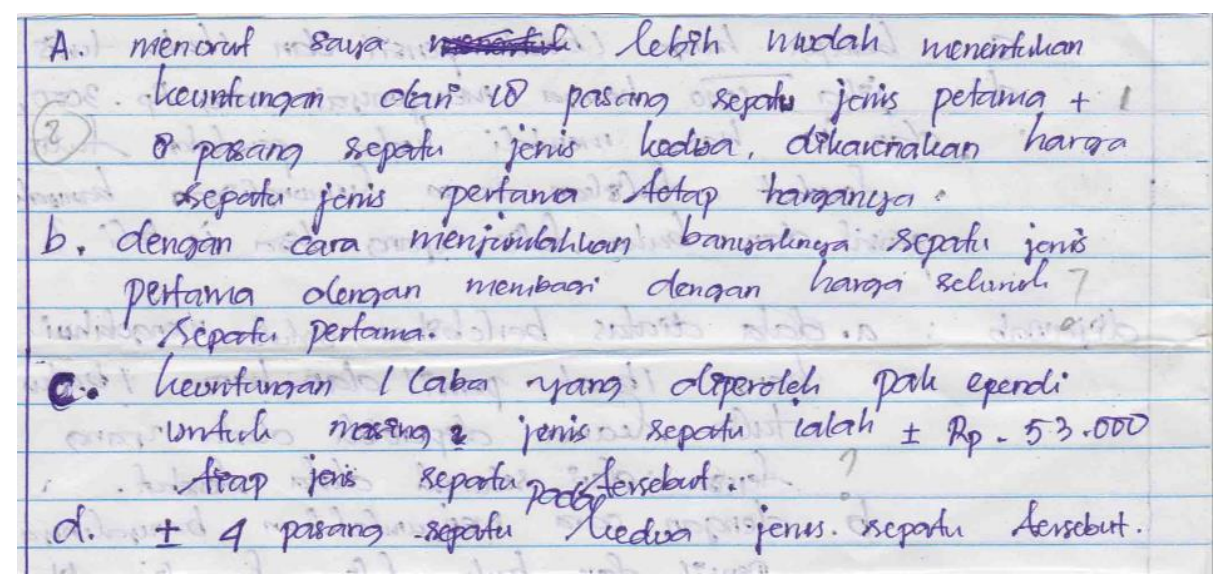

Gambar 3. Pola jawaban siswa di kelas control untuk soal SPLDV (dinilai oleh penulis)

\section{SIMPULAN DAN SARAN}

Berdasarkan hasil analisis data dan temuan penelitian selama pembelajaran kooperatif tipe STAD yang berorientasikan masalah, maka peneliti memperoleh kesimpulan sebagai berikut : Hasil penelitian yang dianalisis secara deskriptif pada kelas VIII (kelas eksperimen), diperoleh bahwa kemampuan pemecahan masalah matematika siswa yang mendapat pembelajaran kooperatif tipe STAD lebih baik jika dibandingkan dengan siswa yang mendapat pembelajaran ekspositori pada pokok bahasan SPLDV. Kemampuan pemecahan masalah ditinjau dari beberapa kriteria yang ditetapkan yaitu : skor rata-rata kemampuan pemecahan masalah siswa yang mendapat pembelajaran kooperatif tipe STAD yang berorientasikan masalah lebih tinggi jika dibandingkan dengan skor ratarata siswa yang mendapat pembelajaran ekspositori. Melalui pembelajaran kooperatif tipe STAD yang berorientasikan masalah membuat siswa lebih aktif dalam pembelajaran. Pembelajaran ini juga membuat siswa antusias dan semangat belajarnya meningkat, tumbuh sikap saling menghargai pendapat dan sebahagian siswa berani menyampaikan pendapat / tanggapan / pertanyaan. Aktifitas siswa membuat siswa menjadi lebih kreatif dan memiliki semangat yang tinggi dalam memecahkan masalah. Pola jawaban yang dibuat siswa yang mendapat pembelajaran kooperatif tipe STAD lebih bervariasi dan sistematis jika dibandingkan dengan pola jawaban siswa yang mendapat pembelajaran ekspositori.

\section{DAFTAR RUJUKAN}

Adinawan, C. 2005. Matematika Untuk SMP/MTs Kelas VIII. Jakarta: Erlangga.

Arikunto, S. 2001. Dasar-Dasar Evaluasi Pendidikan. Jakarta: Bumi Aksara. 
Dahar, Ratna W. 1998. Teori-teori Belajar. Jakarta: Depdikbud.

Dimyati, 2006. Belajar dan Pembelajaran. Jakarta: Rineka Cipta.

Freudenthal, H. 1993. Mathematics as an Educational Task. Freudenthal Institution, Utrecht.

Hamalik, O. 1999. Strategi Baru Strategi Belajar-Mengajar Berdasarkan CBSA. Bandung : Sinar Baru.

Hasanah, A. 2004. Mengembangkan Kemampuan Pemahaman dan Penalaran Matematika Siswa Sekolah Menegah Pertama Melalui Pembelajaran Berbasis Masalah Yang Menekankan Pada Reperesentasi Matematik, Tesis. Bandung: UPI.

Hudojo, H. 1998. Mengajar Belajar Matematika. Jakarta: Debdikbud.

Jarnawi. 2003. Meningkatkan Kemampuan Penalaran dan Pemahaman Matematika Siswa SLTP Melalui Pendekatan Pembelajaran Open-Ended, Disertasi. Bandung: UPI.

Johnson, D.W., Johnson, R.T.. 1994. Cooperative Learning in the Classroom. Alexandria VA: Association for Supervision and Curriculum Development.

Karli, M. Dan Yuliariatiningsih. 2000 . Pengajaran
Berdasarkan Masalah. Surabaya: University Press Karnasih. 2001. Prospek Pendidikan Matematika di Sumatera Utara. Dalam Seminar Sehari 5 Nopember 2001.

Lie, Anita. 2008. Cooperative Learning. Jakarta: PT. Gramedia.

Oakley. 2004. A Theory of Education. Ithaca: Cornell University Press.

Ong Eng Tek. 1999. The Effect of Cooperative Learning on the Mathematics Achievement of Form 4 Students in A Malaysian Secondary School. Journal of Science and Mathematics Education in South East Asia Vol.XXI No. 2

Savery. 2004. Educational Psycology: A Cognitive View. New York: Holt, Rinehart and Winston.

Slavin. 1995. Cooperative Learning : Theory, Research and Practise, Boston Ally and Bacon.

Wardhani. 2006. Contoh Silabus dan RPP Matematika Sekolah Menengah Pertama (SMP), Bahan Ajar Diklat di PPPG matematika. Yogyakarta: PPPG Maatematika.

Zamroni. 2000. Paradigma Pendidikan Masa Depan, Jogjakarta: Bigraf Publissing. 